\title{
EL MITO UNDERGROUND: FERNANDO MÁRQUEZ Y LA NOVELA DE LA MOVIDA
}

Antonio PORTELA LOPA

Universidad de Salamanca

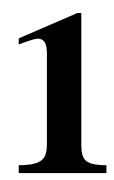

\section{Mary Ann cantó en Kaka de luxe}

Mary Ann, novela que vio la luz en 1985, se caracteriza por pertenecer plenamente a la categoría histórico-artística postmoderna. Afinando los conceptos, podría decirse que, más específicamente, responde a la etiqueta de contracultural, ya que su desarrollo, alumbramiento y difusión tuvieron lugar en el proceso de agitación creativa que vivió España en los primeros años de la Transición. El ambiente de libertad generalizada en la cultura joven de aquellos años ofrece a esta novela un trasfondo ideal para la amalgama de elementos culturales antagónicos. Es un retablo desenfadado que respondería a la corriente «nueva narrativa española» acuñada por los historiadores de la literatura tanto por la mezcla de sus referentes culturales como por la indiferencia con que se trata la tradición literaria (Villanueva, 1987: 33). Por sus páginas desfilan punks junto a escritores, sádicas y violentas impedidas frente a enamorados inconscientes, rockeros frente a hermosas estrellas de cine olvidadas. Un reciente libro editado por Ester Peñas, El eterno femenino (Márquez, 2009), recoge la novela Mary Ann y otros textos (algunos de ellos inéditos) de Fernando Márquez. Está considerado por el autor como una segunda edición a todos los efectos de la obra que ocupará las páginas siguientes.

El autor de esta combinación explosiva es Fernando Márquez, llamado El Zurdo (1957), y ha sido uno de los protagonistas polifacéticos de la Movida madrileña. Autodidacta, se formó con los cómics más que con la literatura. Su vocación musical le condujo a formar parte como letrista y cantante de grupos tan diversos como Kaka de luxe (junto a Alaska, y Nacho Canut), Paraíso, o La Mode. Fue colaborador de Radio 3 y de numerosos fanzines, revistas y periódicos, entre ellos el ABC. Ha sido, asimismo, fundador de la revista El corazón del bosque y la web Línea de sombra. Después de su primera novela (Todos los chicos y chicas, 1980), ha publicado otros cinco libros, y gran parte de esa producción ha estado influida por la obra de Juan Eduardo Cirlot. Cabe destacar, por lo que concierne a la novela que presento, que Fernando Márquez es un autor de obsesiones: una de las más llamativas es la que siente por el protagonista de Psicosis, Norman Bates.

Tres rasgos destacan en Mary Ann. El primero de ellos se refiere a su voluntad genérica híbrida: aunque el género narrativo ocupa la mayor parte del volumen, su epílogo, de gran extensión, se 
presenta en forma de poema «épico». El segundo atañe a la intencionalidad del autor: por un lado, entona su novela a modo de cántico de la vorágine de los tiempos, pero su tono oscila entre lo quejumbroso y lo celebratorio, en una voluntad deliberadamente ambigua. El tercer rasgo destacable reside en la voluntad mítica del autor. Trata de prestigiar un mito del cine clásico de Hollywood (Greta Garbo) actualizándolo culturalmente, con objeto de demostrar su vigencia en tiempos de marcado gusto desmitificador. No en vano se declara el autor «fan de Greta Garbo». Otra obsesión.

\section{La gran belleza y la talidomida}

Mary Ann compone una novela polifónica. Cada uno de sus capítulos se corresponde con una voz narradora distinta, pero todas relacionadas entre sí en la diégesis. El conjunto de la novela depara una obra grotesca y de intenciones provocadoras: el marco en que se inserta la historia lleva impreso el signo de los tiempos (la apertura democrática en España, la relatividad moral, el afán destructivo). Exhibe además un gusto por la enfermedad, por lo monstruoso, por lo prohibido y lo sacrílego. Retrata una especie de mundo al revés donde los mutilados, los impedidos, ostentan un poder de atracción superior.

El amor por los impedidos y la enfermedad entronca directamente con una tradición española de largo alcance, cuyo origen puede rastrearse en Benito Pérez Galdós y en Ramón María del ValleInclán, sin descartar su raíz última cristológica, específicamente católica. Posteriormente, esta fascinación morbosa pasó a formar parte de los vanguardistas. Remite, por ejemplo, al Buñuel de Tristana, adaptación de una novela del mencionado Galdós. El impulso erótico por lo monstruoso (utilizamos esta palabra porque la emplea Fernando Márquez en su texto) es el síntoma también de que la más absoluta Postmodernidad se ha apoderado del arte. La atracción morbosa llega hasta la Movida madrileña, ambiente cultural que acompaña a esta novela y que reaviva los afanes iconoclastas de las Vanguardias. Baste citar el nombre del grupo Parálisis Permanente.

La primera voz narrativa narra una escena que, a modo de impactante preludio, pretende mover la conciencia del lector. El personaje se dirige a comprar a un establecimiento un jersey para su querida Mary Ann. El vendedor le pregunta por las características, mientras que el protagonista va describiendo el jersey perfecto para su amada: no debe tener ningún brazo. Ante las reticencias del comprador por todo lo que el vendedor le va mostrando, decide enseñarle una fotografía que guardaba en la cartera de su amada. Cuando el vendedor descubre la fisionomía y el cuerpo de su amada profiere un grito aterrador. Se acaba de encontrar con la monstruosidad, y, desde ese momento, las situaciones grotescas que parten de las taras físicas de Mary Ann serán constantes a lo largo de toda la novela. Por ejemplo, en esta parte, cuando el comprador asume la imposibilidad de llevarse un jersey a medida para las características de su amada, decide llevarse un poncho como única solución.

El dato más elocuente de Mary Ann reside en que las malformaciones congénitas que sufre se ven compensadas por la extrema belleza de la mitad del rostro de la misma. Así lo describe el amante, que parece decir que la belleza reside en el detalle: 
Nunca me han gustado esas bellezas perfectas, de muñeca, sin vida, sin chispa. Mary Ann tiene un rostro alegre, diverso, lleno de matices opuestos: eso de que le hagan una foto y le pregunten con cierta timidez: «Señorita, eh... ¿le cojo el lado izquierdo?» (Márquez, 1985: 11).

Fernando Márquez se regodea con el concepto de la monstruosidad, partiendo del origen etimológico de la palabra: algo que se debe enseñar, algo que no debe permanecer oculto. Los datos que los narradores van aportando completan el retrato con algún que otro defecto más: a causa de la talidomida, Mary Ann va en silla de ruedas, carece de piernas, tiene una mano palmeada en un muñón de su brazo. En contraste con su deformidad, se ve agraciada con algunos detalles de extrema belleza, extrañamente relacionados con alguna estrella cinematográfica. Entre ellos «el color de su piel -lo más blanco que se ha visto cubriendo un cuerpo femenino-. Me fascina ese color» (Márquez, 1985: 11). El lector se encuentra ante una particular encarnación de la actriz más bella de la historia del cine.

Lo que en Greta Garbo era una belleza artificial, a fuerza de maquillaje y efectos técnicos en el cine, en Mary Ann reside de manera natural. Su mitad facial perfecta compensa las enormes malformaciones de su cuerpo. Pero es una belleza igualmente cinematográfica, como el propio amante le sugiere sarcásticamente: "Yo más de una vez le he dicho a Mary Ann que porqué no se dedica al cine: con esa planta podría ser... un monstruo de la pantalla» (Márquez, 1985: 12). La increíble belleza de su rostro, sólo igualado por el de Greta Garbo, y con el que comparte muchas características que se ahondarán a medida que la novela avanza, contrasta con un chocante carácter. El sistema moral que gobierna en la protagonista es un tanto atípico: elabora junto a su novio unos «panfletos filofascistas», e incluso es capaz de manifestarse a favor de la eugenesia «en los casos de deficientes mentales por herencia» (Márquez, 1985: 13).

Junto a sus imperfecciones y a su extrema belleza, Mary Ann goza de poderes sobrenaturales. Es capaz de levitar, algo que, en la ficción, está acorde con los tiempos de la Movida, que exhibe un gusto por lo sobrenatural insertado en la más absoluta cotidianidad. Recordemos que son los mismos años en que Pedro Almodóvar dota del poder de la telequinesia a la niña protagonista de ¿Qué he hecho yo para merecer esto? (Almodóvar, 1984). O puede invocarse nuevamente a Parálisis Permanente. Uno de sus mayores éxitos, «Quiero ser santa», se ajusta al personaje principal de la novela:

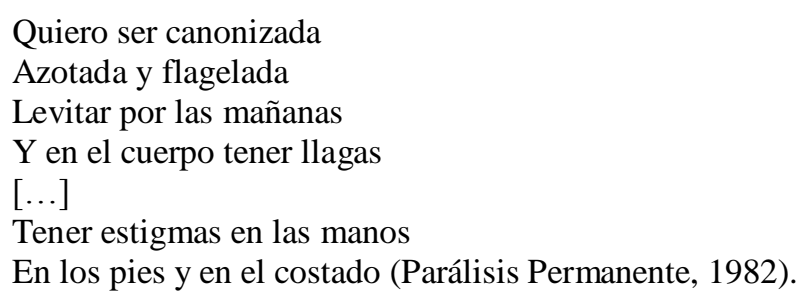

El acontecer de lo monstruoso, pues, se sumará a la fulguración de lo milagroso. La santidad de este personaje es un motivo recurrente en la narración. En una de esas manifestaciones de personas con discapacidad a las que asiste Mary Ann, se relata la sorpresa que causa el uso de sus poderes ante la gente: 
Porque eso fue lo que hizo: levitar. En medio de la manifestación. Varios amputados se pensaron que era la Virgen de Lourdes y prorrumpieron en ensordecedor griterío tirando sus bastones al aire -uno de ellos, por cierto, descerebró a una anciana- (Márquez, 1985: 13).

La comparación de la cita anterior con la Virgen de Lourdes no será la única que apunte hacia el lado divino de la protagonista. Más adelante, se relatará el momento en que un admirador se le acerca y acaba rompiendo en un llanto inconsolable al contemplar su magnífica belleza.

Este mito maltrecho ejerce de reina en el centro de la cultura basura. La novela está plagada de referencias a marcas publicitarias, a grupos de música y a mitos cinematográficos, y todos conviven de una manera singular y sin conflicto. Es un retrato coral de un momento cultural particular y localizado (La Movida), pero también de otro general y global (la Postmodernidad):

\footnotetext{
Me acuerdo de los mitos femeninos que rodearon mi infancia: la Medea de los Argonautas, la Gorgona -hermosa pero con un pequeño defecto capilar-, Madame Hydra -aquel personaje de la MARVEL (Márquez, 1985: 16).
}

Y entre todos esos mitos, uno resalta con especial luz, el de Greta Garbo: «la Greta Gustaffson oculta al mundo y «redescubierta» ahora en unas afrentosas fotos» (Márquez, 1985: 16).

La novela, como se ha apuntado, pretende remover los sentimientos del lector de modo que éste ensanche su corazón hacia los amores poco frecuentes. Aquello que distancia a una persona con plenitud de capacidades físicas de un disminuido es «el desprecio de éste y las inhibiciones de aquél» (Márquez, 1985: 17). La protagonista, objeto de toda la admiración de quienes la conocen, posee pues una mente maravillosa,en un cuerpo extremadamente castigado. En oposición a él, ostenta un rostro tan hermoso o más que aquel que fue calificado como el más bello de la historia.

Este primer narrador apunta mediante prolepsis lo que se referirá con mayor profundidad en el segundo capítulo: Mary Ann vivió un verano con Greta Garbo. En una vida extremadamente intensa para una persona de sus características físicas, resulta un hecho maravilloso que entablara relación con los grandes mitos vivientes del siglo XX:

\footnotetext{
Quién diría que Mary Ann ha vivido treinta años plenos, ha visitado media Europa, ha tenido unos veinte amantes, ha conocido a figuras del Rock y del Cine -pasó un verano con Greta Gustaffson: algún día les hablaré de aquel verano--, ha escrito mucho (Márquez, 1985: 18).
}

Esta mención a Greta Garbo conduce al narrador de esta primera parte a revelar el estatuto que este personaje tiene en la contracultura, como ídolo de minorías marginales:

[...] mito supremo para un pequeño círculo de admiradores entre los dieciocho y los veinticinco años que venderían su alma por estar en mi pellejo (Márquez, 1985: 19).

Mary Ann disfruta enormemente del cine de serie B, en sintonía con su afición al punk, y en general a toda cultura basura. Quizá por esa inclinación a lo marginal, o tal vez como reflejo absoluto de la Postmodernidad más descarnada, Márquez la dota de unos modos de pensar impropios para alguien de su condición. Insolidaria y cruel, no reserva a los de su misma condición el más mínimo atisbo de compasión. Para ella, forman una panda de sentimentales: 
Son inválidos egoístas, caprichosos, neurópatas: si, al menos, tuviesen la clase de Bette Davis, se les perdonaría todo pero, qué va, encima son mediocres y monótonos, justo como el gordo de la película (Márquez, 1985: 22).

El gran parecido que guarda con Greta Garbo también se hace patente en sus modos de vestir y de ocultarse de la gente cuando sale a pasear por la calle. La Divina es más que un modelo de comportamiento para Mary Ann. Ésta es una reencarnación física, moral y estética de la actriz sueca:

En estas salidas suele cubrir el rostro con unas grandes gafas ahumadas y un pañuelo ocultando su boca. Con lo que recuerda a la Greta Gufftason que ella conoció, en increíbles circunstancias, violando su retiro nórdico. Llega incluso, en ocasiones, a encasquetarse un sombrerito de terciopelo negro que parece haber salido de alguna estampa de modas de los años 30. Los escasos paseantes que gustan de mascar soledades como quien le da al tabaco sienten un repeluzno de emoción al contemplar esa fantasmal imagen de la sueca rediviva. A medida que oscurece, vamos internándonos más y más en el parque hasta aislarnos por completo en algún rincón, bajo un árbol o junto al estanque. Entonces, saco a mi Greta de la silla y la deposito en el suelo entre apasionados tornillazos. Ella se quita las gafas y lo mira todo con una expresión helada, reduciendo al mínimo la intensidad de su rictus, como si juzgase lo que ve: el estanque, el palacio de cristal, los cisnes bobos, la hierba, los árboles a medio tonsurar (Márquez, 1985: 23).

Observemos la ironía y el desparpajo con que el narrador de esta primera parte describe la escena citada, que deriva en un impulso incontrolado de exhibición morbosa de lo inadecuado. De nuevo el sentido etimológico de la palabra monstruo cobra sentido. Las peripecias que vivirá el muchacho que relata este primer capítulo con su extravagante amada, se mueven siempre por el mismo deseo de escandalizar. Singular es desde luego la imagen de Mary Ann pidiendo en el metro, y escribiendo carteles para pedir dinero que no responden a la verdad, con la única intención de provocar a los transeúntes la compasión que ella rechaza y abomina. Es el lado cínico del mito que la literatura muestra: «la mitad perfecta de su rostro miraba con altanería a los compasivos que se acercaban y el lado marcado por el rictus imploraba perrunamente» (Márquez, 1985: 25).

Las peripecias amorosas de Mary Ann (entre cines de mala calidad, películas de serie B, metros y bares nocturnos caracterizados por una absoluta libertad) guardan un intenso parecido con las de Greta Garbo. El narrador nos cuenta que debe lidiar continuamente con el intenso magnetismo que su amada irradia. Hombres y mujeres de toda condición se le acercan con intención de conquistarla. Extrañamente, algunos de estos admiradores son el reflejo de los que en otro tiempo Greta Garbo rechazó:

- ¿Vivís juntos?

-Sí.

-Toma mi teléfono. Si alguna vez te quedas sola y necesitas un fan completamente idiotizado por tí [sic], llámame. Hace veinte minutos yo tenía varias amigas y un «plan» serio: ahora sólo hay alguien en mi sesera, tú. No entiendo cómo este tipo tuvo la potra de ser tu compañero... No parece ni sobrehumano ni arcangélico... (Márquez, 1985: 28).

\section{Garbo is Garbo is Garbo}

El comienzo del segundo capítulo trae un cambio de voz narrativa: «Soy una mujer mayor, digamos vieja. 75 años a mis espaldas» (Márquez, 1985: 31). Y, si bien, el lector no sabe todavía a ciencia cierta que quien narra es Greta Garbo, los indicios que Márquez va dejando durante este 
monólogo interior apuntarán a la diosa del celuloide - «y el agua ruidosa, armando escándalo por escapar de la soledad a que me he sometido mi vida y paisajes» (Márquez, 1985: 31)-, caracterizada por un tono de cierta pesadumbre: «Soy la radiografía de mi pasado» (Márquez, 1985: 32). Sólo quien conozca el mito de Greta Garbo relacionará tempranamente esa voz con la actriz sueca: detalles como la afición a tomar el sol y el incordio de los paparazzi remiten a la Divina:

A veces tomo el sol completamente desnuda, en ingenuo afán exhibicionista, a la disposición de cualquier paparazzi tonto. Quiero que el mundo sueñe conmigo, se masturbe conmigo -mejor por mí: yo ya no estoy para...-, sienta conmigo. No puedo soportar esa distancia entre yo hace cuarenta años y ahora. La idiotez del mito me está haciendo difícil el diálogo con mi propio pasado. Las trampas del mundo me están haciendo caer en la trampa de la senilidad. Y la anestesia, que empieza a cubrirme como un traje horrible, esclerotiza mis sentimientos (Márquez, 1985: 32).

Esta Greta Garbo que se va perfilando evoca uno de los momentos más dulces de su vida: su amistad con Mary Ann, ahora lejana. Esta relación se basó en un amor especular. Greta Garbo vio en esta chica un reflejo de la belleza única que la encumbró hacia lo más alto del firmamento cinematográfico. Evoca así su relación con ella:

Si por lo menos estuviera Mary Ann... Era una muchacha inteligente, joven, bonita, tan [sic] bonita como yo. Mirándola me recordaba a mí misma hace mil años: ese orgullo, esa voluntad, esa especie de principio masculino en su carácter, esa ausencia de complejos (Márquez, 1985: 32).

Es de notar que no sólo la belleza atraía a Greta Garbo, sino también su temperamento: ese «principio masculino en su carácter» es también un reflejo del suyo propio. En los años de mayor éxito, se modificó el célebre verso de Gertrude Stein («A Rose is a Rose is a Rose») para aplicarlo a la estrella sueca: «Garbo is Garbo is Garbo». Con ello se incidía sobre la capacidad para interpretarse siempre a sí misma, tanto en las pantallas como en la vida real. La Esfinge era un ser autológico. Y el mito se autoalimenta también, por lo que se infiere del relato de Márquez, en el amor. Porque lo que Greta Garbo apetecía era la unidad con ella misma, más allá del anhelo andrógino, como un ser que no puede darse a nadie más que a ella:

\footnotetext{
O puede que ambas fuésemos una. Mitad y mitad, la ex-actriz comida por los días y el retiro, y la joven dama de compañía comida por la talidomida y el rechazo de una sociedad que no admite monstruos rebeldes a la compasión (Márquez, 1985: 32).
}

La sintonía entre Mary Ann y Greta Garbo también es patente en sus gustos. Resulta llamativo que en este monólogo interior se dediquen algunas reflexiones en torno al movimiento punk. A Greta Garbo este estilo le recuerda a los mejores tiempos vanguardistas de su juventud: «Hay gente que se mete con el punk. Yo recuerdo la tarde que asistí a un concierto futurista en el 26» (Márquez, 1985: 33). Márquez, nuevamente, hace constar que el mito estaba preparado para resistir el embate de los mayores movimientos contraculturales del siglo XX. El punk, como ella, rechaza las convenciones sociales. En el caso de Greta Garbo, las convenciones eran marcadas por la industria cinematográfica, a la que desafió desdeñando sus empeños publicitarios. Su retiro (como un sublime acto de autocontemplación) es tan punk y subversivo como el «No feelings» de los Sex Pistols -«I'm in love 
with myself, myself / My beautiful self» (Sex Pistols, 1977); obsérvese, por lo demás, lo adecuado de la letra para definir la relación entre Mary Ann y Greta Garbo-:

Y la música: ruidos, la «melodía» del progreso. Los punks llevan el pelo corto y visten de oscuro. Algunos se cuelgan la svástica. Los futuristas alababan la guerra y despreciaban a la mujer. Las mujeres punk toman roles «de hombre». Y hay gente que se mete con el punk... (Márquez, 1985: 33).

La novela de Márquez fabula con los rumores en torno al suicidio que acompañaron a la actriz durante gran parte de su retiro de las pantallas. Mediante el recurso de la conciencia subjetiva, se asiste en su monólogo a la concepción estética de la muerte, que debe ser escenificada (inexorablemente para un mito estético del siglo XX) como una performance. Se equipara así al afán autodestructivo que han mostrado algunas de las grandes figuras del rock y del punk (como Sid Vicious):

Debo ir pensando en la forma de suicidio. Nada de sangre, por supuesto: no soporto el dolor físico. Lo más fácil es la sobredosis de somníferos. Pero es tan [sic] vulgar... Y, la verdad, haberme retirado del mundo para acabar de un modo tán $[$ sic $]$ «urbano»... He de pensar en algo curioso, algo que el público pueda comentar: no voy a dejar que los paparazzi se salgan con la suya... «La EX-DIVINA ha sido hallada muerta de asco y barbitúricos en su playa privada»... Los potingues sedantes están bien para chicas como Marilyn, de asfalto y plexiglás. Pero yo soy más «chic», casi KULTUR, y mi suicidio ha de resultar sublime o escatológico, nunca decepcionante. Algún rasgo de humor, sin caer en lo abiertamente cómico: soy una actriz, no un clown. Mi vida y mi muerte han de estar orladas por el misterio y el charme (Márquez, 1985: $35)$.

La su relación con Mary Ann de esta estrella en decadencia derivará en el relato en una escena de intimidad sexual de gran efectividad plástica. El detonante del acercamiento físico entre estas dos divas se desencadena por un intertexto fílmico. Greta Garbo, acomodada en la apacible cotidianidad de los días junto a su amiga y embriagaba «en el delirio de la Juventud y la Belleza» (Márquez, 1985: 38), decide jugar a los papeles que interpretó en el cine:

Una tarde se me ocurrió disfrazarla de Margarita Gautier. Desde el primer día me fijé en el parecido de nuestros rostros, así que, tras estudiar juntas varios primeros planos de mi caracterización en CAMILLE, empecé la transformación (Márquez, 1985: 38).

El acto narcisista de la contemplación se convertirá en pornografía ególatra. El amor que surge en ese momento de simulacro es alentado por la propia fisonomía. Aman sus reflejos. La encendida escena sexual sigue es narrada con gran detalle:

Quizás por narcisismo, pero el último brote de pasión y sensualidad lo sentí al contemplar a «mi doble» estática, fría, más serena que de costumbre, como asumiendo hasta lo más hondo su disfraz. Yo, saco de huesos, hembra fósil, me estaba viendo en un cuerpo atroz y, sin embargo, resplandeciente de atractivos. Fue un goce narcisista, cierto: saber que, aunque la Naturaleza «me» hubiese marcado con horribles rictus y mutilaciones, «yo» iba a seguir siendo bella... No lo pude evitar: abracé aquel cuerpo maltratado, aquellos muñones, aquella absurda mano palmípeda, y besé a mi imagen sin espejo completamente borracha de plenitud, de saber que Mary Ann era la plenitud, que yo en mi juventud fuí [sic] ella, más que ella, sin mancha ni defecto. Por un momento me puse en el pellejo de mis admiradores y, admirándome, la admiré a ella. Caímos sobre la alfombra: en pocos minutos, la fiebre de aquel infantil y ególatra deseo nos arrancó las ropas. Durante una hora nos amamos hasta el agotamiento. Mi boca, mis ojos, mis manos recorrieron a Mary Ann con un frenesí de teenager. Mis ajadas mejillas se dejaron acariciar por la insólita extremidad, sin sentido pero capaz de expresar los más sutiles afectos. Mis dedos se deslizaron por el torso suave y elástico, perfecto en sí mismo, sólo nublado por la carencia de lo que, gracias a la mente, no necesitaba... Mi lengua cruzó y requetecruzó al otro lado del espejo, perdiéndose en fantásticas plantaciones de hierbabuena, en brillos de 
rosa casi blanco, en umbrías ocultas entre muñones... El común sudor y todas las comunes secreciones de placer empaparon la alfombra y, a su vez, el sueño nos empapó (Márquez, 1985: 38-39).

Fundidas al fin en un solo ser se produce el colapso. Poco tiempo después de aquella escena de amor, obscena y natural como los amores míticos grecolatinos, Mary Ann parte abandonando a Greta Garbo, justificando su decisión como único modo de preservar sus mitos. Greta Garbo, como todos los que conocen a la singular mujer discapacitada, convirtió su amor en dependencia. Pero de ella misma:

Yo llegué a necesitarla, a precisar de su compañía, pero en todo momento acechaba la sombra del común parecido, de mis pulsiones narcisistas, de intentar utilizarla en mi irracional batalla contra el Tiempo: si ella hubiese tenido otro rostro... (Márquez, 1985: 39).

El cierre de este extenso monólogo interior asume un valor representativo del resto de la novela: «soñaré conmigo. Con Mary Ann» (Márquez, 1985: 40).

\section{La destrucción punk o el amor}

El tercer capítulo nos presenta otra voz narrativa. El lector se percata con ella que las voces que pueblan la novela tienen en común que han mantenido una intensa relación de amor con Mary Ann. En este caso se trata de Pepito, un punk que la busca desaforadamente en los parques de Londres, y que siente desconfianza hacia su manager, con quien mantiene una relación a cambio de favores. Cuando el muchacho no encuentra a Mary Ann, sospechará de este manager. Este personaje resulta interesante por cuanto dictamina que, en las claves de la mentalidad punk, caben las grandes estrellas cinematográficas como parte de su repertorio cultural vivo. Por ejemplo, Pepito las emplea para describir a Mary Ann: «en ocasiones me recordaba a la Dama pero otras era salvajemente dulce, tierna como estas heroínas cinematográficas del Pasado» (Márquez, 1985: 47).

Márquez guarda otra delicatesen dedicada a los verdaderos mitómanos de Greta Garbo. Pepito y Mary Ann comparten chicles de hierbabuena porque ella no soporta el mal aliento. En más de una ocasión Greta Garbo rehusaba completar escenas en sus rodajes porque sus compañeros de reparto no exhalaban un aliento fresco:

Entonces me ofreció un chicle de hierbabuena. Yo, para demostrar que era muy punk, me lo tragué con envoltorio y todo. Ella se rió y me explicó que mascaba chicle para tener un aliento fresco. Yo no entendía lo del aliento y le dije que el aliento del punk es fétido y que Johny Rotten tenía los dientes verdosos. Ella hizo un gesto de repugnancia y replicó que era una suerte escuchar a los SEX PISTOLS sin tener que oler el aliento del cantante (Márquez, 1985: 48).

Las consecuencias de haber conocido a Mary Ann son las mismas para Pepito que para las dos voces anteriores. Deja tras de sí un rastro de destrucción. Quien ha conocido al mito (aunque sea su versión deformada) no puede conocer la felicidad: «Pronto, la noticia se corrió por todos los clubs: mi chica favorita se había convertido en una institución. / Hoy, todos los que la conocieron, no sólo la Dama y yo, se sienten más vacíos, más pesimistas, más “no future”» (Márquez, 1985: 52). El poso de melancolía que deja es insalvable. 
La voz narrativa del cuarto capítulo presenta el mayor número de similitudes con el autor. Se llama, como él, Fernando y se presenta en calidad de fan de Greta Garbo. Como realizando los deseos del propio Fernando Márquez, relata el momento en que le presentaron por primera vez a esta discapacitada, tan parecida a su gran obsesión mítica. El encuentro es de una intensidad casi divina: «Apreté su mano durante un instante que me pareció una eternidad, trastornado por la vergüenza y fascinado por sus facciones medio iluminadas que me traían a la memoria otro rostro, otra época...» (Márquez, 1985: 54). La belleza de Mary Ann produce un efecto turbador en el narrador, que continúa describiendo su belleza:

Frente a mí tenía a una Greta Gustaffson mutilada y deforme y, sin embargo, radiante de pura belleza. Como si ningún defecto hubiese maltratado su físico. La revelación elevó en unos instantes la fascinación ejercida. Porque su mirada, su palidez, ante aquella certeza, adquirían unos tonos capaces de romper cualquier equilibrio (Márquez, 1985: 63).

El parecido de la Mary Ann con Greta Garbo no sólo es físico, sino también ficticio. En este caso el intertexto se establece con Ninotchka: «No paraba de reir [sic]. Su cuerpo terminaba a la altura de la ingle. Toda su piel parecía cubierta por un maquillaje de clown: tál [sic] era su ausencia de color» (Márquez, 1985: 64). La novela despliega un recorrido por todas las estaciones que jalonan el mito. Nos encontramos próximos al final de la novela, como Ninotchka se hallaba casi al final de la filmografía de la Divina. Por ello se muestra ahora la cara más amable de Mary Ann, la que sabe reír. La experiencia estética del personaje de Fernando se convierte en experiencia mística, en una unión indisoluble entre el mito y el admirador:

Era difícil mantener la conciencia del propio acto de amor junto a aquella diosa primordial, tán [sic] irracionalmente femenina que se salía de su sexo, elevándose a cotas sublimes, dando al encuentro primerizo una categoría de secuencia mística, algo tan lleno de efectos que buscarle un mero valor erótico carecería de sentido (Márquez, 1985: 65).

Pero su lado más cercano contrastaba con su poder destructivo, que permanecía inalterable:

La única realidad posible era que quien hubiese jugado al amor con Mary Ann quedaba seco para el resto de sus días, incapaz de sentir el imán de otras mujeres, las cuales encogerían en ridícula imagen ante el recuerdo de la única piel blanca, de la única serenidad sobrehumana, de la única capacidad de entrega que jamás llega a la renunciación total (Márquez, 1985: 65).

La narración de Fernando acaba con unas reflexiones en torno a la naturaleza divina del mito, y a la posibilidad de consumar con el un amor que de otro modo no sería posible. En la consumación se padece de primera mano lo destructivo de una relación tan intensa:

Todos los misterios que saben los grandes locos «d'amour», desde Carroll hasta alguna gente que conozco, se resumen en el Misterio Supremo del encuentro inesperado, de la virgen-macho llamando al claustro sacro del dios-hembra. De Mary Ann, la cual, en su salvaje deformidad y asimetría, era, es y será LA MUJER MAS BELLA DEL MUNDO.

Así fue como la conocí (Márquez, 1985: 65).

El último capítulo, titulado «Flashback, Apéndice al capítulo IV», ofrece menos interés mítico. La narradora es ahora la Dama, una lesbiana que también padeció el amor de Mary Ann. Esta parte, 
no obstante, ofrece las claves culturales con las que se articula la novela, sintetizada en las palabras de uno de sus personajes: «-Estos punks... No respetan ni a sus muertos» .

\section{5. «Post-Greta»}

El epílogo a la novela de Fernando Márquez, titulado «Post-Greta», es el resumen del ambiente cultural en que se desarrolla la novela, pero su entidad particular lo constituye en texto autónomo. Se trata de un largo poema que apunta pormenorizadamente los rasgos culturales que permitieron la supervivencia del mito de la actriz en la literatura más subversiva. A través de su extensa proclama, demuestra que un mito de la altura de Greta Garbo es capaz de establecer por sí mismo una nueva época artística y social. En la hipérbole que supone aplicar al mito el poder de establecer nuevos períodos históricos (como Cristo), Fernando Márquez constata que su admiración por la actriz sueca cruza los límites de lo establecido. El autor se coloca frente al mundo, en un acto de protesta contra quienes proclaman la muerte (y el escaso peso en el arte) de la Divina. La operación postmoderna del texto de Márquez está gobernada por un afán rebelde desde un mito que podría considerarse ya clásico en el año de publicación de su novela. Merece la pena detenerse en este significativo epílogo.

Esas pretensiones disidentes le conminan a comenzar su poema situándose frente al mundo, que parece haber relegado al mito a una época clausurada de la cultura:

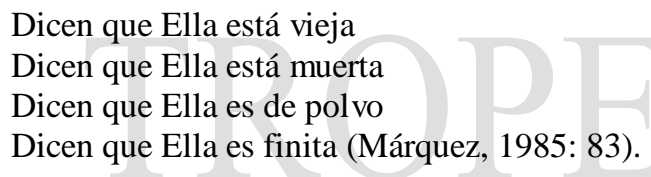

Frente a ellos, agrupados en ese «dicen» que encabeza el elocuente paralelismo, Fernando Márquez adopta la posición de quien conoce de primera mano el mito y no está dispuesto a enterrarlo. Esgrime para ello argumentos culturales contra las normas e ideas arcaicas que siguen alumbrando a los hombres. La libertad que airea el ambiente social de aquellos años, parece querer decir Márquez, se limita a lo superficial. La religión, la ideología, la naciente democracia en España («se reúnen en semicírculo para mandar a quien no obedece») pertenecen a ese grupo vetusto y sagrado de valores:

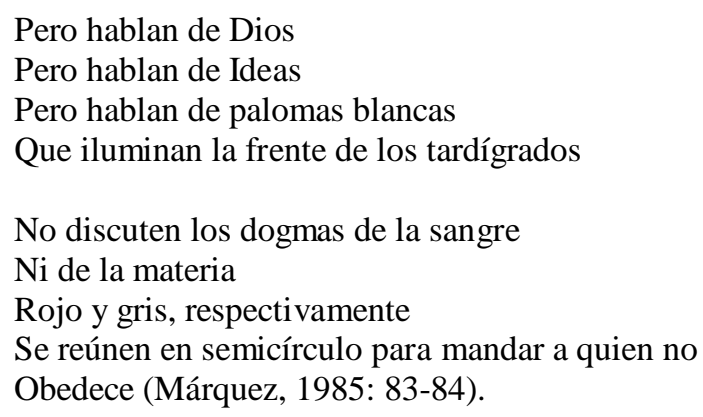

Junto a estas emanaciones sagradas han surgido otras formas de la divinidad, como los medios de comunicación, que, en teoría, también se sumergían en el territorio de la libertad general. Por ello, los siguientes versos aluden a la liberación del cuerpo en los media (la época del destape), y a la difusión de la droga como divertimento, simbolizada en España por aquella arenga viciosa de 
«Rockeros, el que no esté colocao que se coloque y al loro» de Enrique Tierno Galván, como un lema podrido de la corrupción postmoderna:

Se rasgan las bragas y las puntillas por la tele

Lloran lágrimas de gin-fizz por el Destino del Hombre

Luego sonríen, en pleno trance anfetamínico,

Y bailan el bugui de la confianza (Márquez, 1985: 84).

El poema presenta la paradoja de la Postmodernidad, mediante la cual quedan abolidos (idealmente) los dogmas, pero se crean otros nuevos de igual intensidad letárgica sobre la conciencia. Pero Márquez, un autor inmerso en el centro de esta época, detecta que la cultura de masas, la alta cultura y la contracultura siguen compartiendo, a su juicio, los viejos ideales como principios inmutables. Toda cultura, prístina o actual, es objeto de la suspicacia del autor. Es otra de las formas del cinismo:

Se puede creer en la eternidad del Supremo

Se puede creer en la eternidad de la Idea

Se puede creer en la eternidad del Santo Buchón

Se puede creer en la eternidad de la sangre

Se puede creer en la eternidad de la materia

En tanto en cuanto dinámica de la Historia (Márquez, 1985: 84).

Pero Fernando Márquez se alza como una voz que clama la falsedad de todo tipo de creencias establecidas, y pretende abrir los ojos de los hombres a la realidad, desvelar el círculo de falsedades en que se encierra el hombre contemporáneo cuando se ampara en la religión y la ideología. El poema se escora hacia zonas blasfemas e incendiarios. Proyecta una sombra de relativismo acorde con los tiempos: da lo mismo que se siga al Obispo de Roma, que la gente se refugie en las nuevas encarnaciones de la divinidad en la cultura de masas falsamente desacralizada, o que se entreguen a la orgía de las ideologías,

\author{
Porque Dios no existe \\ Porque los comunistas son unos malvados \\ Porque la exacerbación nacionalista trae graves consecuencias \\ Porque hay que seguir al Papa Godzilla \\ Que vuela bajo los soles al grito de SHAZAM!!! (Márquez, 1985: 84).
}

El poema fluctúa entre la soflama mesiánica (por su tono) y la oda nihilista punk (reforzada por el uso del verso libre y variado, sin estructura fija ni uso de estrofas clásicas). Se nombra a Greta Garbo ahora como encarnación de un tiempo salvador, de una estabilidad artística y cultural genuino, pleno de substancia. Ella establece tras su desaparición de las pantallas el año cero del cine, del Arte. Es Cristo cinemático. Cierra una época y abre otra. Fernando Márquez deja ver que cualquier artista que le siguió caía irremediablemente en el manierismo, cuando no en la más absoluta futilidad en la interpretación. Porque el arte interpretativo de Greta Garbo ha sido una de las artes más refinadas que haya podido contemplar, hasta el punto de no ser arte (como se ha apuntado más arriba). Ni siquiera otros mitos considerados como tales, como Bette Davis, pueden resistir la comparación con el mayor (¿y único a juicio de Márquez?) mito que ha dado la pantalla. 


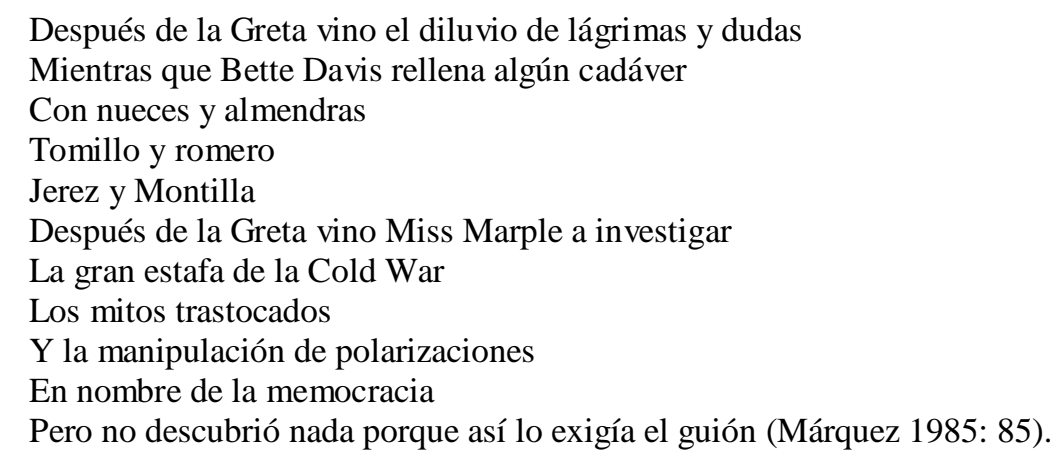

En la cita anterior se puede ver en qué modo cambió el arte cinematográfico después de recibir la figura de Greta Garbo. Todo se sentimentalizó, se hizo demasiado evidente y se desprendió de la finura y la elegancia. Después de ella, como un punto Alfa y Omega de la historia, los géneros cinematográficos se volvieron aburridos: Miss Marple simbolizaba la vacuidad del séptimo arte entendido en su más prosaico mercantilismo; «la gran estafa de la Cold War» alude al thriller político, otro género masivo y evidente. También tras Greta Garbo vinieron «los mitos trastocados», sometidos a la manipulación fílmica que les resta encanto. A difundir esos mitos desvirtuados y sin sustancia contribuían las técnicas cinematográficas que las hacía vulgares: «y la manipulación de polarizaciones / en nombre de la memocracia». Desde que la Divina abandonó las pantallas, el arte tiene como único valor llegar al mayor número de público posible mediante la estandarización y el uso simplista de los recursos técnicos. Esta circunstancia abrió la puerta a la «catástrofe».

Porque después de instaurada esta nueva época artística el único resultado de toda práctica cultural es la tristeza. El mito de Greta Garbo, ofrecía a sus admiradores y al arte cinematográfico en general, el optimismo de lo refinado. Mediante esta mística cultural se establecía entre el admirador y la estrella una relación basada en la intimidad. Era un arte de la evocación, de lo delicado, de la elegancia, nunca de lo vulgar. Después, el excesivo uso de la carne y el reclamo del sexo en las películas, dejaba poco espacio para la imaginación del público. El cine se convertía en lo superficial. En lo éxtimo y lo práctico:

\footnotetext{
Después de la Greta vino el tedio y el desamor El racionamiento de la fantasía El sexo multiplicado por mil, como esporas Las dicotomías y los análisis (Márquez, 1985: 85).
}

En este tenso punto cultural del poema irrumpe la primera persona. Pero el género de este epílogo imprime forzosamente un carácter alejado de las voces que han narrado la vida y milagros de Mary Ann, desterrada del poema. El yo lírico del poema se impone como autoridad. Después de haber esbozado el panorama cultural y político que ha empujado al autor hacia la mitificación de Greta Garbo, y de haber impuesto y marcado sus distancias con ese mundo vulgar y falta de imaginación, esta voz se ve abocada a aparecer para realizar un acto de fe artística: 
Y -cómo no-

De Ella (Márquez, 1985: 86).

Un rayo de esperanza se ilumina en medio del caos impuesto por la Postmodernidad y la contracultura. El autor alberga el deseo de que la gente despierte de su letargo cultural y otorgue a Greta Garbo la categoría que se merece. Hay que venerarla como una diosa, porque ésta sí es real, porque proporcionó todo aquello que hace poco formaba parte del sistema religioso. Frente a todas las canonizaciones culturales que se suceden vertiginosamente hay que discriminar entre lo genuino y lo falso:

Quizás ahora alguien se atreva a canonizarla

Porque ya está bien de santas con bigote y verruguilla

Porque ya está bien de santos que, por el hecho de parecerse a Manuel Puig

Y no escribir como Manuel Puig, ya son santos (Márquez, 1985: 86).

A pesar de estar inmerso en esta frenética semiosis de los banal, el autor se escandaliza de la desintegración de los valores que el mito de Greta Garbo atesoraba. Frente a la concepción caótica de la realidad, impuesta por el pensamiento postmoderno, donde todo parece ser posible y el relativismo nivela figuras de muy distinta altura cultural, Fernando Márquez aboga por retornar al mito de Greta Garbo. El relativismo proclama por un lado la libertad, mientras por otro condena al individuo a la espiral de silencio, en aras de la corrección política mediante la censura social. La mezcla postmoderna queda simbolizada y retratada en el último verso de la siguiente cita, donde lo antiguo, caracterizado todavía por pertenecer a un sistema prestigioso de la sociedad, está condenado a ir de la mano de realidades contemporáneas de bajas aspiraciones:

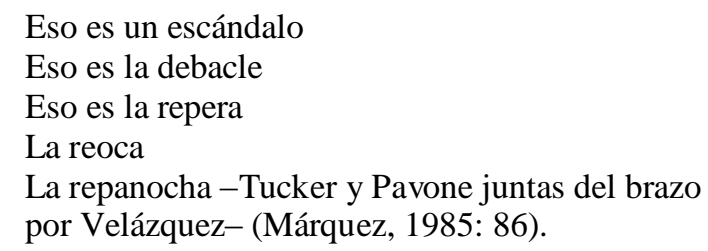

El poema, como se desprende de todo lo citado hasta el momento, se concibe como una larga letanía, un género frecuentado por el mito. Las letanías se caracterizan por la repetición, sometiendo a las palabras a un vaivén inagotable. Induce al lector a un estado de conciencia suspendido. En la siguiente cita, siguiendo estas estructuras, se expresa un nuevo catálogo de modelos cinematográficos que siguieron a Greta Garbo. Los mitos que se crearon después de ella no tenían ni la calidad suficiente ni la potencia necesaria para ser considerados como tales. Nunca el mito de Greta Garbo, parece indicar Márquez, pisó el lodazal de la vulgaridad:

Después de la Greta vino la Guerra

Después de la Greta vino la Pazzzzzzzzzzzzzzzz

Después de la Greta vino la náusea

Después de la Greta vino la arcada del gordo aquél

Que vomitaba hamburguesas y blues mal digerido

Y también vino James Dean a vender pantalones pero la Porsche lo saboteó

-malditos teutones!!!- (Márquez, 1985: 87). 
Los versos siguientes, «Freud vino después de la Greta / Porque... ¿a quién le importaba Freud cuando se estrenó CAMILLE?» (Márquez, 1985: 86), desmontan otro mito del siglo XX. Al margen de Freud, Greta Garbo había instaurado una nueva dimensión en la conciencia de los espectadores, que permitía sin los laberintos freudianos entender la mente a través de la complejidad de su arte. Su calidad plasmó los deseos ocultos y reprimidos de la psique. Márquez se revela como un maestro de la hipérbole. Greta Garbo provenía de una zona del tiempo no mensurable con los patrones que gobiernan los días de la humanidad. Después de ella, vinieron algunos hitos en la historia. Uno de ellos proviene de la literatura, y el otro del tiempo de la historia, pero ambos han sido sometidos a la mitificación:

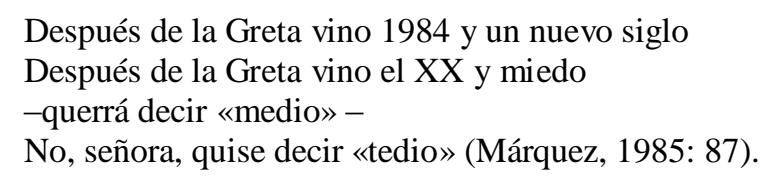

1984 es un año mítico que ha dado lugar a una gran labor intertextual. La referencia a la novela de Orwell trae otras engendradas a partir de la fábula apocalíptica, como la canción homónima de David Bowie: «Beware the savage jaw / of nineteen eighty four» (Bowie, 1974). Pero, a pesar de toda la carga simbólica que arrastra, aquel año no resiste el embate de Greta Garbo. El otro parámetro histórico, el siglo XX, venía acompañado de todos los males que hoy son objeto de queja: las estructuras sociales y los sistemas morales ya no respetan a los antiguos, aunque estos sean actores de cine.

\footnotetext{
Después de la Greta vino Cristina Keller

Disfrazada de Modesty Blaise

Programada para cachondearse eternamente de

Ramón Novarro (Márquez, 1985: 87).
}

Márquez considera que Greta Garbo, que arrastraba tras de sí un tiempo, instauró también un nuevo sistema filosófico. Resulta imposible discernir aquí entre la ironía y el instinto. Nietzsche en su momento había pronosticado la muerte de los dioses, pero Greta Garbo matizó la radicalidad de la afirmación del filósofo al manifestarse ella misma como diosa:

\footnotetext{
Después de la Greta los huesos de Nietzsche estaban más que lirondos porque él nunca la conoció -¿O SI?- (Márquez, 1985: 87).
}

Fernando Márquez se pregunta por el destino de Greta Garbo una vez que abandonó las pantallas. Empleando su apellido, Fernando Márquez el autor intenta preguntarse qué fin ha tenido su diosa, oculta y lejana: «Nadie sabe qué ha sido de Miss Gustaffson después de la Greta» (Márquez, 1985: 87). Quizá busque un punto estable en el torrente nihilista en que se anegaba la cultura pop. Porque después de Greta Garbo las mayores estrellas del punk, iconoclastas y pretenciosos, se proclamaron portavoces del nuevo sentir. Es el caso de Patti Smith, a cuya canción «Pissing in a river» hace referencia en el siguiente verso: 


\author{
Después de la Greta vino Patti Smith meándose de gusto \\ Mujer-buitre enamorada de Rimbaud \\ Que, seguramente, en su vida ha visto un film de la Divina \\ Porque, en tal caso, cambiaría de estética y pasiones (Márquez, 1985: 88).
}

Y como se puede ver por las duras palabras proferidas por Fernando Márquez en la cita anterior, reduce a payasada la intrascendente actitud mesiánica de la diva del punk. No entiende el autor por qué se engrandece la figura de esta cantante. La categoría de anti-héroe que se le otorga ya la había merecido en su momento Greta Garbo, y en un grado mucho mayor. Greta Garbo fue, en definitiva, la primera punk de la historia (idea desarrollada en el cuerpo de la novela). Acto seguido, Márquez retoma en los siguientes versos las grandes películas de la época que siguieron a la Divina:

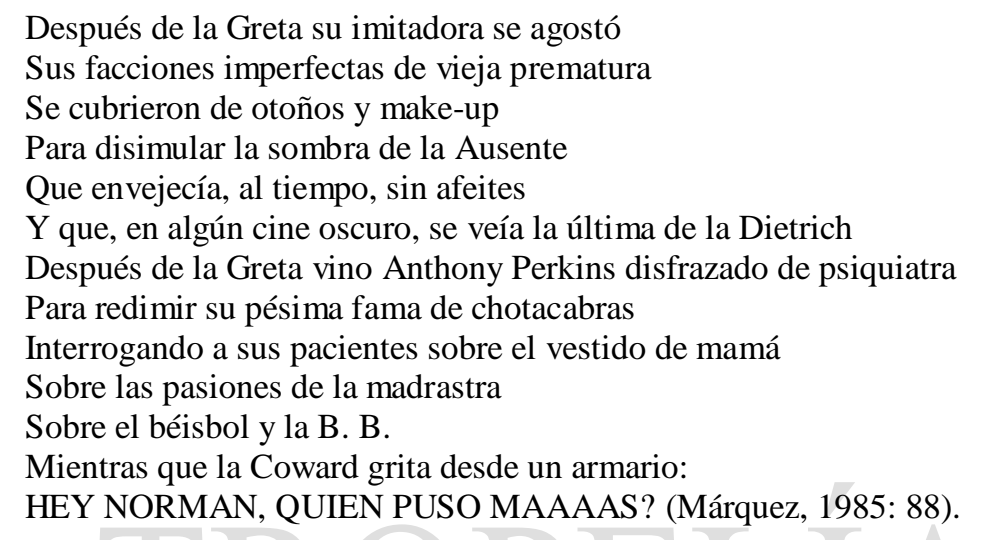

Gran parte de la actitud contracultural se resume en la negación constante y consciente de los elementos instalados en el repertorio cultural. El curso de la historia ha deparado que la época posterior a Greta Garbo abriera los sistemas morales. La Postmodernidad había virado hacia el relativismo moral, que en el tiempo de Greta Garbo todavía se manifestaba de manera unitaria y no relativista. Por ello Fernando Márquez, irónicamente, advierte en los siguientes versos sobre la permisividad del pecado y lo prohibido, que conduce a un estado hipócrita de las relaciones humanas:

Después de la Greta todas las incipientes libertades

Se volvieron tolerancias

Y el monumento al Hipócrita Más Conocido

Sustituyó al de aquel joven soldado imposible de identificar (Márquez, 1985: 89).

De nuevo el juego de palabras, sustentado en la similitud fónica, aparece en el poema de Fernando Márquez. En este caso, mediante una paronomasia. Las «grietas» se convierten en símbolo de la inestabilidad cultural:

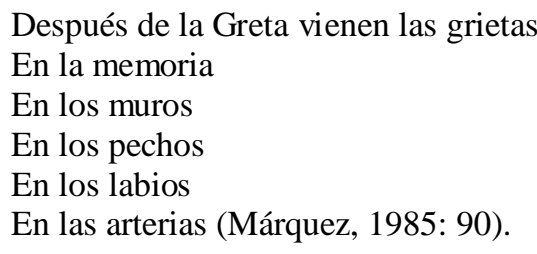


Las grietas minan los cimientos de un mundo que se desintegra, y que instaura una nueva relación del hombre con la cultura que lo circunda. A pesar de ello, Fernando Márquez detecta algunos personajes que podrían haber alzado el vuelo hacia el estado mítico propugnado por Greta Garbo. Pero aún así, en estos grandes hitos de la cultura de masas no se encuentra un atisbo de mito, de la altura que alcanzó Greta Garbo en su momento. Todo está gobernado por una intensa mediocridad:

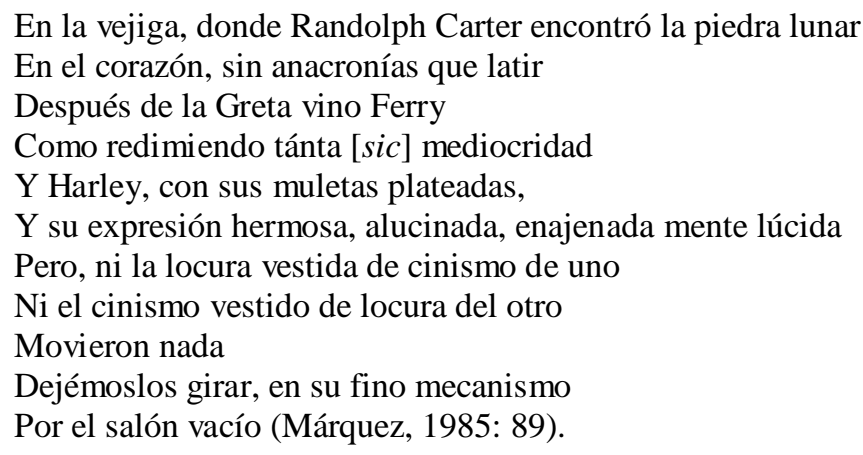

La época que cierra Greta Garbo llevó consigo un modo de hacer cine, un Hollywood dorado bajo cuyos auspicios la realidad no importaba. Era un horizonte estético de la belleza. Se primaba la grandeza de sus estrellas y la sublimación de la realidad misma. Porque después de Greta Garbo, el sentimiento de mediocridad inundó también el cine. Las estrellas se cifran en el signo de lo corriente, que en el esquema estético de Fernando Márquez se traduce en vulgar. Greta Garbo corresponde a una etapa del cine verdaderamente trágica porque se movía en los niveles altos de la cultura. Después de ello, la tragedia no puede ser posible. El rechazo del antihéroe por parte de Fernando Márquez no deja de resultar paradójico (su novela está plagada de estas figuras, como se ha tenido oportunidad de ver), pero en el fondo estos personajes buscan la sublimación de la realidad:

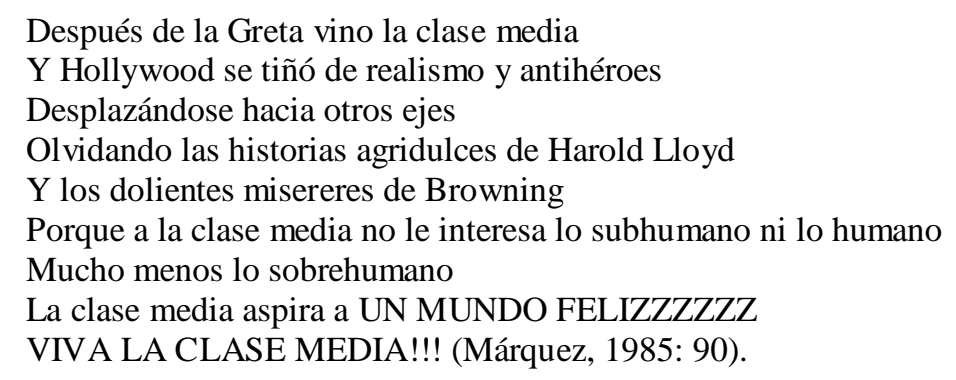

La clase media es el reflejo de la estandarización de los modelos. No busca indagar en los insondables misterios del alma humana. Por ello se contenta con producciones cinematográficas vulgares que no apuntan hacia un orden sublime de las cosas. Los escenarios burgu eses, de la nueva clase media, inundan ahora las producciones cinematográficas y rebajan el nivel de altura que habían alcanzado las obras artísticas en el tiempo de Greta Garbo. Se impone una moral de la corrección, algo que no altere el estado natural del orden burgués y de la clase media, para la que debe existir siempre una utilidad. Esta utilidad puede ser ideológica, o puede ser simplemente cultural. Interpretando los versos de Márquez, la clase media quiere que todo tenga una función, que todo obedezca a un orden, cualquiera que éste sea (el orden mercantil, el orden ideológico, el orden social): 


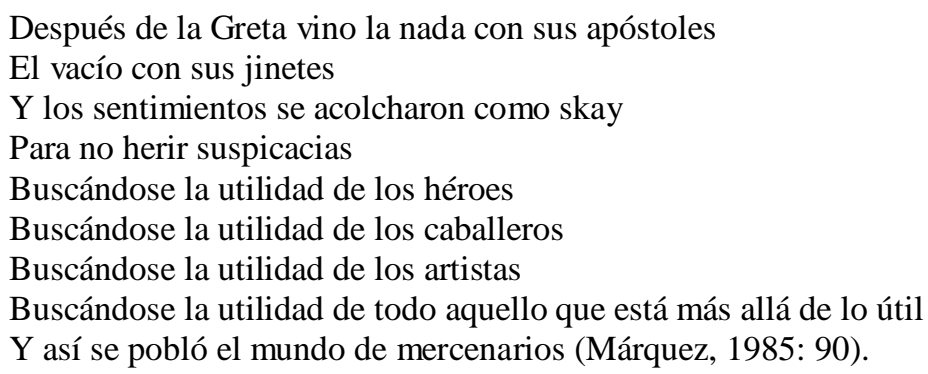

La elegancia del arte de Greta Garbo ya no es comparable con nada. La belleza será absoluta o no será. El anhelo de Fernando Márquez se dirige al ideal de la belleza sin más, sin sentido utilitario, con el único propósito de que vuelva su majestad al reino de lo mediocre instaurado tras su desaparición. La «armonía» que encarna Greta Garbo en la pantalla ya no puede volver, porque la realidad y el modo de pensar burgués lo frenan, lo prohíben y cercenan. Y la burguesía encuentra un gusto en la comparación con los mitos caídos, con el afán de la sociedad por derribar los mitos y la ceguera de no leerlos ni interpretarlos correctamente, sino como una realidad prosaica y vulgar, reducidos a la muerte como cualquier ser mortal:

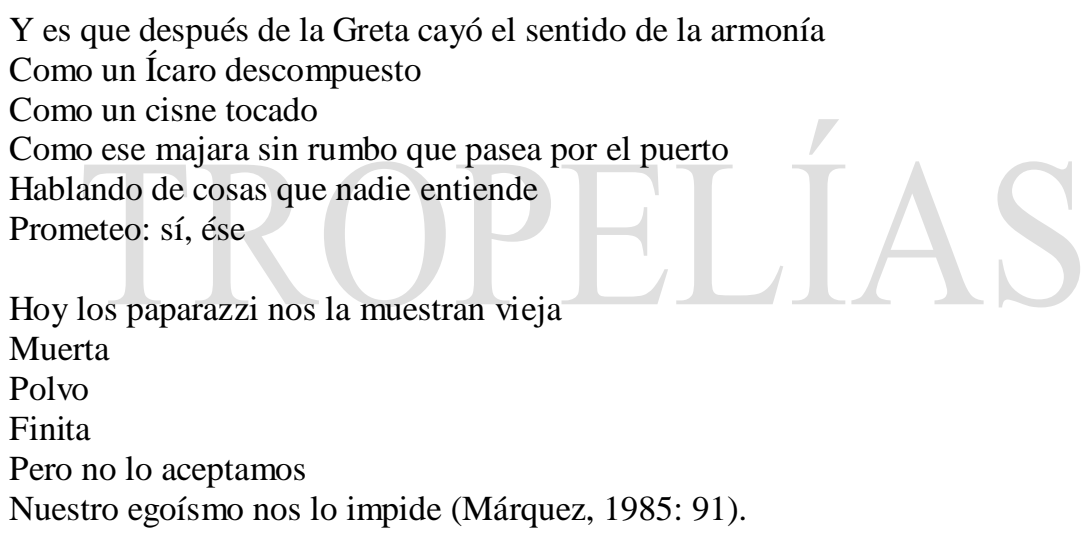

Pero como el propio Fernando Márquez deja entrever en los siguientes versos, su corazón guarda un resquicio de esperanza. Llega a la conclusión de que hablar de un después de Greta Garbo es encontrarse ya en otra época, un tiempo en el que se atisba el final de una época. Por su eso su poema se yergue como un canto profuso y torrencial, elegíaco y jubiloso a un tiempo: «Porque reconocer el «después» de la Greta / Es reconocer el final de todo» (Márquez 1985: 91).

El final del poema avanza hacia un tono religioso y profético. El sentimiento contradictorio de esta nueva época guarda en sí una gran energía, pero por ello mismo corre el riesgo de derivar en destrucción. Como arte joven encuentra en la devastación de lo antiguo, en el regocijo nihilista, un placer porque todo sea nuevo. Pero, por otro lado, el amor hacia el mito mitiga esas ansias. Reconduce, pues, esa energía hacia lo bello del renacer:

Y aún sentimos la locura en nuestras venas

Aún nos vemos con fuerza para desafiar al nihilismo

Para trastocar todos los órdenes

Para organizar los mayores escándalos

Para esperar entre las sombras lo inevitable (Márquez, 1985: 92). 
El renacimiento de la belleza provendrá del mito. Márquez ha cesado de buscar los nuevos ídolos entre el desorientador predio de la Postmodernidad. Como aguardando un segundo advenimiento de Cristo/Greta Garbo, se despierta el anhelo de que llegue pronto la nueva época, escrita sólo con los renglones de lo sublime. Recordemos que Humberto Salvador la había metaforizado como estrella del portal de Belén. Se espera

El Gran Milagro

LA RESURRECCION DE LA FANTASIA

LA PELICULA SIN FIN DE GRETA GARBO (Márquez, 1985: 93).

\section{A modo de conclusión: ¿fue Greta Garbo una protopunk?}

Mary Ann demuestra la vigencia del mito cinematográfico de Greta Garbo a pesar de las relecturas radicales a las que se le somete. Evidencia que, mientras otros mitos establecidos socialmente son rechazados en la llamada contracultura, llevándolos a un proceso de desintegración, de desfuncionalización, los mitos surgidos en la cultura de masas permanecen estables porque se han engendrado como mitos contraculturales. $\mathrm{O}$, dicho en términos biológico-literarios, el mito en la cultura de masas está marcado por el gen de la contracultura. La cultura de masas puede ser acogida en el sistema de llegada como referente contra el dirigismo de las instituciones educativas que son las que forman el canon cultural. Hay que tener en cuenta que la contracultura ha sido entendida como una revolución cultural que desmontaba la tradición (Villena, 1975).

Estableciendo una analogía con las manifestaciones literarias, la posición del mito en la cultura es similar a la que tienen los textos ambivalentes. Este concepto, desarrollado por Zohar Shavit (en origen es de Lotman, pero era aplicado en un sentido más restringido), aclara el funcionamiento de ciertas creaciones literarias en el sistema cultural según la posición que ocupan en él y el uso de los modelos y el público al que va dirigido. La definición del u so que hace Shavit del término ambivalencia aclarará por qué es rentable en su aplicación al mito:

Estos textos pertenecen simultáneamente a más de un sistema y, en consecuencia, se leen de forma diferente (aunque al mismo tiempo) por parte de dos grupos de lectores al menos, que divergen en sus expectativas así como en sus normas y hábitos de consumo (Shavit, 1999: 151).

No debe olvidarse que el mito de Greta Garbo ha vivido el paso de la Modernidad a la Postmodernidad. Existen ejemplos tempranos de la mitificación desde presupuestos anclados todavía en la Modernidad: la caracterización como heroína cultural (y su mutación en la de consumo) o la vinculación con los mitos antiguos son sólo algunos parámetros derivados de la Modernidad que ejercen su poder sobre la interpretación del mito. Pero, aun en los momentos en que el mito fue acogido e interpretado bajo la égida de la Modernidad existen indicios que dejan ver en el mito el germen de la contracultura.

La actriz Greta Garbo, la persona real, fue tempranamente celebrada por su carácter antisocial, por su misterio o por su incierta sexualidad. En resumen, su persona y sus personajes cinematográficos 
(especialmente los que le confirieron la fama de femme fatale) conformaron un texto -una semiótica textual se hace necesaria para el mito- que circuló desde el primer momento de su carrera hollywoodiense como un ser contracultural. Llevaba implícitas todas las contradicciones de los mitos postmodernos, entre los cuales Greta Garbo resultó ser un caso paradigmático.

Quizá por ello su mito estuviera preparado para la época neo-cínica en que vivimos ahora. La «voluntad subversiva» de los antiguos cínicos los condujo a emprender una marcha «antiprometeica» con objeto de echar «por tierra todas las conquistas técnicas y culturales» (Daraki y Romeyer-Dherbey, 1996: 8). Textos como el de Fernando Márquez son, traducidos a lenguaje contemporáneo, proclamas antisistema de la literatura con la presencia impasible del mito al fondo. Utilizo cínico en el sentido estricto, tanto en su origen griego de secta del perro (García Gual y Diógenes Laercio, 1987), como en su actualización contemporánea en la línea de una auténtica contracultura, defendida por Sloterdijk en su Crítica de la razón cínica (Sloterdijk, 2007).

En medio de los escombros de la Postmodernidad sólo el mito queda en pie. Así lo demuestra Fernando Márquez mediante la paradoja: en momentos de gran inestabilidad cultural, cuando el centro de la cultura es rechazado en favor de la periferia, lo mítico se yergue como un centro estable. Greta Garbo está sustraída del tiempo. Ya está, por tanto, preparada para afrontar cualquier época. Esta es una idea claramente desarrollada en el epílogo, que resume las bases ideológicas que el autor articula en torno al mito. El viaje en el tiempo del mito de Greta Garbo ha revelado su visionaria génesis revolucionaria. Por ejemplo, el lesbianismo de Greta Garbo, con el que tanto se especuló, no sólo es aceptado en los tiempos en que la novela se publica (y así se verá en el relato) sino que forma ya parte del comportamiento natural de la juventud, que ha destruido viejos prejuicios. Incluso podría decirse que los personajes de la novela actúan como si nunca los hubiera habido.

La melancolía que perfilaba la belleza de Greta Garbo era una forma protesta artística. Siempre ha formado parte de su significado, como podemos comprobar en las palabras de Béla Balázs, quien intentó desentrañar tempranamente el misterio de la heroína Garbo:

Greta Garbo is sad. Not only in certain situations, for certain reasons. Greta Garbo's beauty is a beauty of suffering; she suffers life and all the surrounding world. And this sadness, this sorrow is a very definite one: the sadness of loneliness, of an estrangement which feels no common tie with other human beings. [...] / Millions see in her face a protest against this world, millions who may perhaps not even be conscious as yet of their own suffering protest; but they admire Garbo for it and find her beauty the most beautiful of all (Balázs, 1952: 286-287).

Cierro este recorrido por la incendiara novela sin apuntar el posible carácter simbólico de la imagen de Mary Ann: su parecido con Greta Garbo invita a considerarla un trasunto temporal acomodado a los tiempos contemporáneos. Fragmentada, apenas irreconocible, pero conservando las esquirlas de la grandeza icónica que en su momento conformaron el monumento a la belleza más grande que ha conocido el cine. Respondiendo a una consulta del autor de este artículo, Fernando Márquez explica lo siguiente:

De Mary Ann y de su novia La Divina, sólo diré lo que ya dije en su momento cuando se me preguntó por la razón de ser de este libro: que un punto de Greta Garbo en un cuerpo extremamente talidomídico y 
con medio rostro deformado, vale por todas las bellezas convencionales que los cánones de la moda y de los quirófanos han dado. La belleza es llama y misterio y revulsión y catarsis (al menos, para mí): lo contrario de la belleza no es la fealdad (criterio sumamente resbaladizo) sino el bostezo.

En esta nota explicativa se aprecia la noción de punto, el punctum que el mito aporta a todo texto y a todo cuerpo. También resulta llamativa y contundente la redifinición de belleza, que corresponde al mito y a sus custodios, los poetas. Frente a ellos, pugnan por el cetro de la hermosura los medios de masas y los cirujanos plásticos.

\section{Bibliografía}

Almodóvar, P. (1984): ¿Qué he hecho yo para merecer esto? Madrid, Tesauro / Kaktus.

BALÁzs, B. (1952): Theory of the Film: Character and Growth of a New Art. Londres, Dennis Dobson LTD.

BOwIE, D. (1974): Diamond Dogs. Londres, EMI Records.

DARAKI, M., y ROMEYER-DHERBEy, G. (1996): El mundo helenístico: cínicos, estoicos y epicúreos. Madrid, Akal.

García Gual, C. / Diógenes Laercio (1987): La Secta del perro / Vidas de los filósofos cínicos. Madrid, Alianza Editorial.

MÁrqueZ, F. (1985): Mary Ann. Madrid, Ediciones Libertarias.

— (2009): El eterno femenino. Edición de E. Peñas. Barcelona, Ediciones El Cobre.

PARÁLISIS PERMANENTE (1982): «Quiero ser santa», en Quiero ser santa (EP). Madrid, Tres Cipreses. SEX PISTOLS (1977): Never Mind the Bollocks. Londres, Virgin.

Shavit, Z. (1999): «La posición ambivalente de los textos. El caso de la literatura para niños», en M. Iglesias Santos, ed., Teoría de los Polisistemas. Madrid, Arco/Libros, pp. 147-182.

SLOTERFIJK, P. (2007): Crítica de la razón cínica. Madrid, Siruela.

VillanueVA, D. (1987): «La novela», en A. Amorós, ed., Letras españolas 1976-1986. Madrid, Castalia, pp. 19-64.

VILLENA, L. A. DE (1975): La revolución cultural: desafío de una juventud. Barcelona, Planeta. 